\title{
Morphology and Morphometry of the Distal Articular Surface of Lunate Bone in a Kenyan Population
}

\author{
Morfología y Morfometría de la Superficie Articular Distal \\ del Hueso Semilunar en Una Población de Kenia
}

Johnstone M. Muthoka*; Wycliff O. Kaisha*; Gachambira Gikenye* \& Julius A. Ogengo*

MUTHOKA, J. M.; KAISHA, W. O.; GIKENYE, G. \& OGENGO, J. A. Morphology and morphometry of the distal articular surface of lunate bone in a Kenyan population. Int. J. Morphol., 34(3):896-900, 2016.

SUMMARY: The morphology and morphometry of the distal articular surface of the lunate exhibits inter-population variations. They are of clinical importance to hand surgeons due to their influence on the occurrence of proximal pole arthrosis which is a cause of ulnar-side wrist pain. The objective of the study was to determine the morphology and morphometry of the distal articular surface of the lunate bone in an adult Kenyan population. A descriptive cross-sectional study at the Department of Human Anatomy, University of Nairobi. Fifty-six human hands obtained for routine dissection were used. The morphology of the distal articular surface of the lunate was classified as either Type I or Type II depending on the absence or presence of a medial facet for articulation with the hamate respectively. The width of the wrists and of the medial facet in Type II lunates was measured with SOMETTM CN-25 1234 vernier calipers (accurate to $1 \mathrm{~mm}$ ). Photomacrographs of representative lunate were taken. Data were analyzed using SPSS version 17.0. The Pearson correlation test was used to check for any correlations. Type II lunate morphology was more common with a prevalence of 34 $(61 \%)$ while $19(34 \%)$ were Type I. The mean width of wrists with Type I lunate was $41.1 \pm 2.8 \mathrm{~mm}$ while those with Type II had a mean width of $46.1 \pm 4.3 \mathrm{~mm}$. The mean width of the medial facet in lunate type II was $4.4 \pm 1.4 \mathrm{~mm}$. Lunotriquetral fusion was demonstrated in 3 (5\%) wrists. Prevalence of Type II lunate was higher than Type I. Wrists with a Type II lunate were wider than those with Type I. There was no correlation between the width of the wrist and the width of the medial facet of the lunate.

KEY WORDS: Hand; Lunate; Wrist; Kenyan.

\section{INTRODUCTION}

According to variations in the distal articular surface of the lunate, the bone has been categorized into Type I and Type II. A Type I lunate has one distal facet for articulation with the capitate while a Type II lunate has an additional facet medially for articulating with the hamate (Viegas et al., 1990; Nakamura et al., 2001; Dharap et al., 2006a). The prevalence of the Type II lunate ranges from $26.7 \%$ to $73.3 \%$ and shows population variation (Viegas et al., 1993, Dharap et al., 2006a).

Type II lunate is more prone to degenerative changes in the hamato-lunate joint (HLJ) that may cause ulnar-sided wrist pain (Burgess, 1990; Viegas et al., 1993; Nakamura et al., 2000; Galley et al., 2007; Haase et al., 2007). In Type II lunates the width of the accessory facet ranges from 1-12 mm (Viegas et al., 1993; Lamas et al., 2007). Proximal pole arthrosis of the hamate occurs not only in the presence of Type II lunates but also if the width of the medial facet (MF) exceeds $3 \mathrm{~mm}$ (Nakamura et al., 2001).

*Department of Human Anatomy, University of Nairobi, Nairobi, Kenya.
Wrists with a Type II lunate are larger in terms of length and width (Sagerman et al., 1995; Dyankova et al., 2007). Correlation of width of wrist with width of MF in type II lunate may allow morphometric estimation of the width of the MF from in vivo measurements of wrist width and hence the likelihood of proximal pole arthrosis as a cause of ulnar-sided wrist pain.

This study aimed at determining the prevalence of type 2 lunates and when present, correlating the width of the MF and the width of the wrist.

\section{MATERIAL AND METHOD}

Fifty-six (56) disarticulated hands were obtained from the dissection laboratory at the Department of Human Anatomy, University of Nairobi. Data was collected by a sin- 
gle observer in two sittings. Intra-observer variability was mitigated by taking two measurements and recording the average.

For each hand, measurements were taken using a pair of vernier calipers (SOMETTM CN-25 1234; accurate to 1 $\mathrm{mm})$. The width of the wrist was measured across the mid-carpal joint and recorded. The lunate was identified from the proximal aspect between the scaphoid laterally and the triquetrum medially and incisions made to free it. Fascia and connective tissue were cleaned off and the distal articular surface was exposed by division of the dorsal intercarpal ligaments. Observation of the distal articular

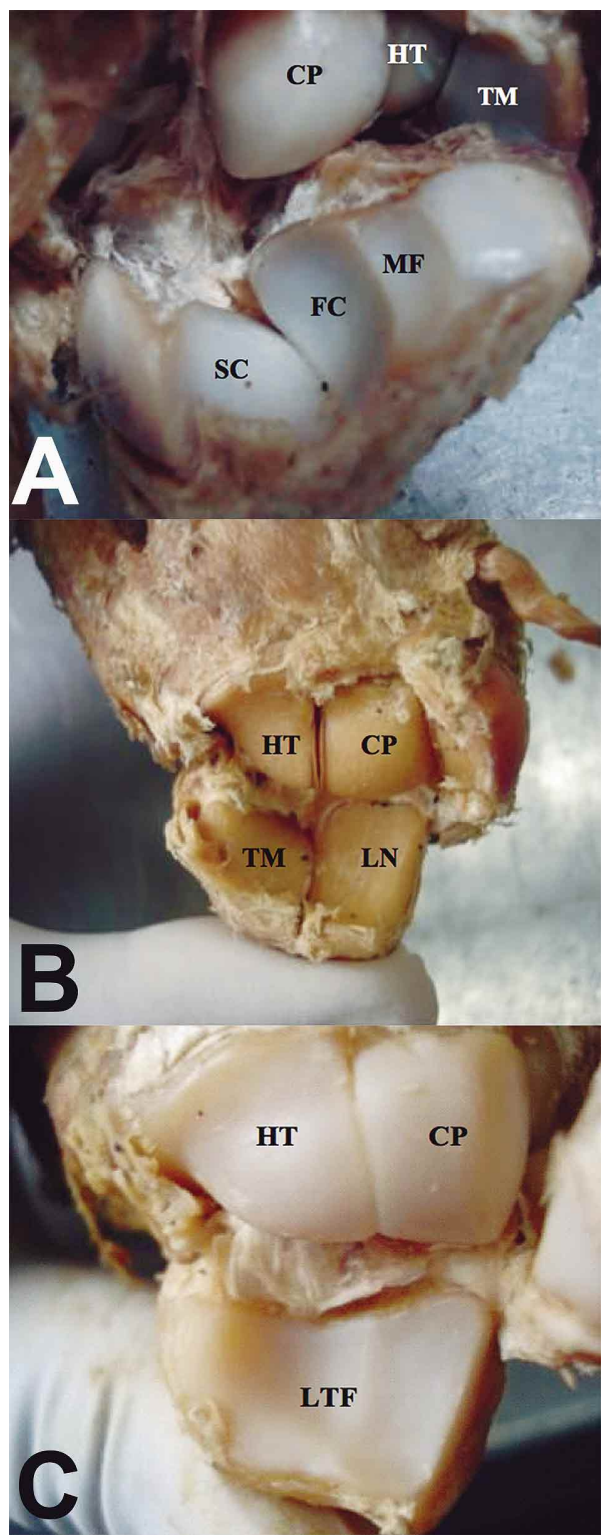

surface for the presence of the MF for the HLJ was done. This classified each lunate as either Type I or Type II. The width of the medial facet in Type II lunate was measured and recorded. Representative photographs were taken using a digital camera (Sony Cybershot R, DSC W50, 7.2 Megapixels).

Data Analysis. Recorded observations of lunate types and measurements of wrist width and MF width were tabulated and analysis done using SPSS Version 17.0 (for Windows ${ }^{\mathrm{TM}}$ SPSS Inc., Chicago, III). Frequencies and percentages of the prevalence of morphological types of Lunate were calculated. Means, standard Deviations and ranges of the morphometric data were then computed. Due to the ratio-type of data collected, the Pearson's correlation test was used to correlate measurements of wrist width with width of MF in type 2 lunates.

\section{RESULTS}

Fifty-six (56) human wrists (34 left and 22 right) were analyzed in this study. The morphological types of lunate described by Viegas et al. (1990) were observed.

According to the prevalence of Lunate types, out of the 56 wrists studied, $34(61 \%)$ showed Type II Lunate (Fig. 1A), whereas 19 (34 \%) had Type I Lunate (Fig. 1B). Lunotriquetral fusion (Fig. 1C) was seen in $3(5 \%)$ of the specimens. Representative photomacrographs are shown overleaf.

In the comparison of wrist width, the mean width of wrists with type I lunate was $41.1 \pm 2.8 \mathrm{~mm}$ with a range of $37-46 \mathrm{~mm}$ and a median of $41 \mathrm{~mm}$. In Type II wrists, the mean width was $46.1 \pm 4.3 \mathrm{~mm}$ with a range of $38-55 \mathrm{~mm}$ and a median of $46 \mathrm{~mm}$.

According to the width of medial facet, the average width of the medial facet was $4.4 \pm 1.4 \mathrm{~mm}$. The median was $4 \mathrm{~mm}$ with a range of $2-7 \mathrm{~mm}$ though most $(65 \%, \mathrm{n}=34)$ had a width of $4-6 \mathrm{~mm}$ as shown below in the Figure 2.

The Pearson correlation test was used to carry out the analysis. There was no correlation between the width of the wrist and the width of the MF ( $p=$ 0.226 at $95 \%$ CI.

Table I. Showing morphometric parameters of wrists according to lunate type.

\begin{tabular}{lccc}
\hline Type of lunate & $\begin{array}{c}\text { Mean wrist } \\
\text { Width } \pm \text { SD }(\mathbf{m m})\end{array}$ & Range (mm) & Median (mm) \\
\hline I & $41.1 \pm 2.8$ & $37-46$ & 41 \\
II & $46.1 \pm 4.3$ & $38-55$ & 46 \\
\hline
\end{tabular}

Fig. 1. Photomacrographs showing distal articular surfaces of lunate types. A) Type II lunate in which the distal articular surface has two facets; one (FC) for the capitate and a medial facet (MF) for the hamate (HT). Note the scaphoid (SC) and the triquetrum (TM). B) Type I lunate in which the distal articular surface (LN) has a single facet for articulation with the capitate $(\mathrm{CP})$. Note the hamate $(\mathrm{HT})$ and the triquetrum (TM). C) Lunotriquetral fusion (LTF) in which a fused lunate and triquetrum articulates with the hamate (HT) and capitate (CP). 


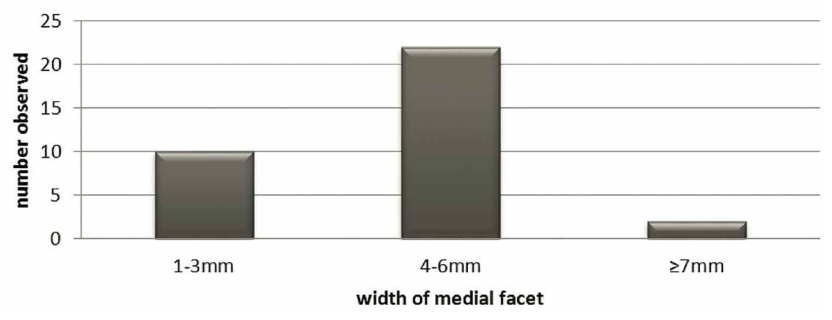

Fig. 2. Bar graph showing relative distribution of medial facet width.

\section{DISCUSSION}

Observations of the current study revealed that in the Kenyan population, the Type II lunate has a higher prevalence, occurring in $34(61 \%)$ than type I lunate which occurred in 19 (34 \%). Both are within the range reported in literature (Table II). Prevalence of Type II lunate varies in different populations with the highest prevalence of $73 \%$ recorded by Viegas et al. (1990) in Texas (USA) and the lowest of $26.7 \%$ recorded by Dharap et al., (2005) in Malaysia (Table II). These differences may be due to varied ethnicities of the populations studied. Pertinent to this suggestion is an inference by Dharap et al. (2006b) which points to genetics as the reason for these observations.

The presence of a medial distal facet in type II lunate is associated with different movement patterns and ligamentous attachment in the wrist (Galley et al.). More important, it is associated with cartilage erosion and arthrosis at the HLJ which causes ulnar-sided wrist pain (Nakamura et al., 2000; Haase et al.). In a study based on 2D motion analysis of the lunate, Nakamura et al. (2000) suggested that differences in motion, joint loading and injury patterns may contribute to this higher incidence of arthrosis in wrists with Type II lunate. Subsequently, it was also noted that there was a higher incidence of arthrosis at the HLJ if the medial facet was $3 \mathrm{~mm}$ or more (Nakamura et al., 2001).
In our population the incidence of Type II lunate is relatively high, $(61 \%, \mathrm{n}=56)$ and $71 \%$ of them had a medial facet width of 4-7 mm. This varies from report by Nakamura et al. (2001) in an American population in which $78 \%$ had a medial facet width of 1-3 mm. This suggests that arthrosis at the HLJ may be a significant cause of ulnar-sided wrist pain in the Kenyan population. Clinicians may find this information useful in modifying their approach to management of ulnar-sided wrist pain within this population.

Anthropometric studies have shown statistically significant differences in wrist dimensions depending on lunate type. In a study by Dyankova, the basic anthropometric characteristics (length, width and height) of wrists with lunate Type II were larger than those with lunate Type I. In our study the average width of wrists with lunate Type I was $41.1 \pm 2.8 \mathrm{~mm}$ with a range of $37-46 \mathrm{~mm}$. In Type II wrists, the mean width was $46.1 \pm 4.3 \mathrm{~mm}$ with a range of 38-55 mm, thus supporting reports that wrists with Type II lunate are larger than wrists with Type I lunate.

The use of $\mathrm{x}$-rays to determine lunate morphology has limited predictive value and may therefore be inaccurate in examinations done to determine the cause of ulnar-sided wrist pain (Sagerman et al.). We had postulated that a correlation between the width of the wrist and the width of the medial lunate facet in lunate Type II may provide a better way of determining lunate morphology. Using a Pearson's correlation test we found that there was no correlation between the two parameters $(\mathrm{p}=0.226$ at $95 \% \mathrm{CI})$ and thus wrist width cannot be used to determine lunate morphology.

In this study, an interesting finding was that in $5 \%$ $(n=56)$ of wrists there was Lunotriquetral fusion of the complete type according to the classification of Devilliers Minnaar (1952). This is consistent with literature reports of $9 \%$ among blacks (Szaboky et al., 1969). Carpal bone coalition may be congenital or acquired. Congenital coalitions are due to a failure of segmentation and cavitation

Table II. Showing the prevalence of lunate types in different countries. $*=5 \%$ had Lunotriquetral fusion.

\begin{tabular}{lccccc}
\hline \multirow{2}{*}{ Author } & \multirow{2}{*}{ Year } & \multirow{2}{*}{ Country } & \multirow{2}{*}{ Number } & \multicolumn{2}{c}{ Incidence \% } \\
\cline { 5 - 6 } & & & & Type $\mathbf{1}$ & Type 2 \\
\hline Viegas et al. & $(1993)$ & USA & 393 & 27 & 73 \\
Arai et al. & $(1993)$ & Japan & 127 & 42.5 & 57.5 \\
Aufauvre et al. & $(1999)$ & France & 100 & 44 & 56 \\
Nakamura et al. & $(2001)$ & USA & 170 & 29 & 71 \\
Dharap et al. & $(2005)$ & Malaysia & 90 & 73.3 & 26.7 \\
Dharap et al. & $(2006)$ & Bahrain & 381 & 61.2 & 38.8 \\
Current study* & $(2016)$ & Kenya & 56 & 34 & 61 \\
\hline
\end{tabular}


at a site of future joint space within the carpus (Gam et al., 1976). Acquired coalitions can occur secondary to arthritis, trauma or as a metaplastic conversion of intra-articular structures to bone. It may also be a result of surgery done for joint stabilization (Poznanski \& Holt, 1971).

Such coalition may present symptoms such as carpal tunnel syndrome, ulnar nerve neuropathy and pain under exhausting conditions such as repeated prehensile movements, playing musical instruments and strenuous sporting activities (Singh et al., 2003). This suggests that in cases of these conditions, coalition of carpal bones should be considered as a differential diagnosis.

As limitations, it was not possible to determine the gender of specimens thus variations according to gender were not studied. Further studies are needed so as to document the handedness of the individuals and the prevalence of carpal bone coalition. There was a shortage of data on the incidence and management of wrist pain in our local setup and we propose that clinical studies be carried out to provide a basis for better management of this clinical entity in our population.

\section{CONCLUSION}

In this study, incidence of Type II lunate was higher than Type I and this may point to proximal pole arthrosis as a cause of ulnar-sided wrist pain in our setup. There was no correlation between the width of the wrist and the width of the medial facet of the lunate. Carpal bone coalition is present in our population.

MUTHOKA, J. M.; KAISHA, W. O.; GIKENYE, G. \& OGENGO, J.A. Morfología y morfometría de la superficie articular distal del hueso semilunar en una población de Kenia. Int. J. Morphol., 34(3):896-900, 2016.

RESUMEN: La morfología y morfometría de la superficie articular distal del hueso semilunar muestra variaciones entre la población. Es de importancia clínica para los cirujanos de mano debido a su influencia en la incidencia de la artrosis del polo proximal, que causa dolor ulnar en la muñeca. El objetivo fue determinar la morfología y morfometría de la superficie articular del hueso semilunar en una población adulta de Kenia. Estudio descriptivo de corte transversal, realizado en el Departamento de Anatomía Humana de la Universidad de Nairobi. Se utilizaron 56 manos humanas que fueron sometidas a disección de rutina. La morfología de la superficie articular distal del hueso semilunar se clasificó en Tipo I o Tipo II en función de la ausencia o presencia de una faceta medial de la articulación. El ancho de las muñecas y de la faceta medial en el Tipo II se midió con el caliper SOMETTM CN-25 1234 (precisión de $1 \mathrm{~mm}$ ). Se tomaron macrofotografías representativas del hueso semilunar. Los datos fueron analizados con el programa SPSS versión 17.0. Se utilizó la prueba de correlación de Pearson. La morfología del hueso semilunar Tipo II fue más frecuente con una prevalencia de 34 casos $(61 \%)$, mientras que 19 casos $(34 \%)$ eran de Tipo I. El ancho promedio de las muñecas del hueso semilunar Tipo I fue de 41,1 $\pm 2,8 \mathrm{~mm}$, mientras que las de Tipo II fue de 46,1 $\pm 4,3 \mathrm{~mm}$. El ancho promedio de la cara medial del hueso

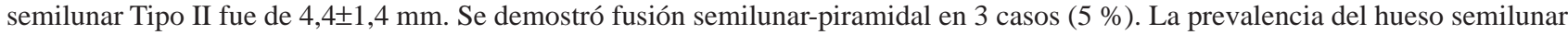
Tipo II fue mayor que la del hueso semilunar Tipo I. Las muñecas que presentaban hueso semilunar Tipo II fueron más anchas que las de Tipo I. No hubo correlación entre el ancho de la muñeca y el ancho de la faceta medial del hueso semilunar.

PALABRAS CLAVE: Mano; Hueso Semilunar; Muñeca; Keniano.

\section{REFERENCES}

Burgess, R. C. Anatomic variations of the midcarpal joint. J. Hand Surg. Am., 15(1):129-131, 1990.

Devilliers Minnaar, A. B. Congenital fusion of the lunate and triquetral bones in the South African Bantu. J. Bone Joint Surg. Br., 34-B(1):45-8, 1952.

Dharap, A. S.; Al-Hashimi, H.; Kassab, S. \& Abu-Hijleh, M. F. The hamate facet of the lunate: a radiographic study in an Arab population from Bahrain. Surg. Radiol. Anat., 28(2):1858, 2006a.

Dharap, A. S.; Lutfi, I. \& Abu-Hijleh, M. F. Population variation in the incidence of the medial (hamate) facet of the carpal bone lunate. Anthropol. Anz., 64(1):59-65, $2006 \mathrm{~b}$.

Dyankova, S. Anthropometric characteristics of wrists joint surfaces depending on lunate types. Surg. Radiol. Anat., 29(7):551-9, 2007.

Galley, I.; Bain, G. I. \& McLean, J. M. Influence of lunate type on scaphoid kinematics. J. Hand Surg. Am., 32(6):842-7, 2007.

Garn, S. M.; Burdi, A. R. \& Babler, W. J. Prenatal origins of carpal fusions. Am. J. Phys. Anthropol., 45(2):203-8, 1976. 
MUTHOKA, J. M.; KAISHA, W. O.; GIKENYE, G. \& OGENGO, J. A. Morphology and morphometry of the distal articular surface of lunate bone in a Kenyan population. Int. J. Morphol., 34(3):896-900, 2016.

Haase, S. C.; Berger, R. A. \& Shin, A. Y. Association between lunate morphology and carpal collapse patterns in scaphoid nonunions. J. Hand Surg. Am., 32(7):1009-12, 2007.

Lamas, C.; Carrera, A.; Proubasta, I.; Llusà, M.; Majó, J. \& Mir, $\mathrm{X}$. The anatomy and vascularity of the lunate: considerations applied to Kienböck's disease. Chir. Main, 26(1):13-20, 2007.

Nakamura, K.; Beppu, M.; Patterson, R. M.; Hanson, C. A.; Hume, P. J. \& Viegas, S. F. Motion analysis in two dimensions of radial-ulnar deviation of type I versus type II lunates. J. Hand Surg. Am., 25(5):877-88, 2000.

Nakamura, K.; Patterson, R. M.; Moritomo, H. \& Viegas, S. F. Type I versus type II lunates: Ligament anatomy and presence of arthrosis. J. Hand Surg. Am., 26(3):428-36, 2001.

Poznanski, A. K. \& Holt, J. F. The carpals in congenital malformation syndromes. Am. J. Roentgenol. Radium Ther. Nucl. Med., 112(3):443-59, 1971.

Sagerman, S. D.; Hauck, R. M. \& Palmer, A. K. Lunate morphology: can it be predicted with routine x-ray films? $J$. Hand Surg. Am., 20(1):38-41, 1995.

Singh, P.; Tuli, A.; Choudhry, R. \& Mangal, A. Intercarpal fusion - A review. J. Anat. Soc. India, 52(2):183-8, 2003.

Szaboky, G. T.; Muller, J.; Melnick, J. \& Tamburro, R. Anomalous fusion between the lunate and triquetrum. J. Bone Joint Surg. Am., 51(5):1001-4, 1969.

Viegas, S. F.; Patterson, R. M.; Hokanson, J. A. \& Davis, J. Wrist anatomy: incidence, distribution, and correlation of anatomic variations, tears, and arthrosis. J. Hand Surg. Am., 18(3):463$75,1993$.

Viegas, S. F.; Wagner, K.; Patterson, R. \& Peterson, P. Medial (hamate) facet of the lunate. J. Hand Surg. Am., 15(4):56471,1990 .

\author{
Correspondence to: \\ J. M. Muthoka \\ Department of Human Anatomy \\ University of Nairobi \\ P.O Box 30197,00100 \\ Nairobi \\ KENYA
}

Tel: +254-724814435

Email: muthokajm@gmail.com

Received: 22-01-2016

Accepted: 05-05-2016 